\title{
Shakespeare's Coinage
}

\section{Richard Proudfoot}

\section{(2) OpenEdition \\ Journals}

Electronic version

URL: http://journals.openedition.org/shakespeare/1258

DOI: 10.4000/shakespeare.1258

ISSN: 2271-6424

\section{Publisher}

Société Française Shakespeare

\section{Printed version}

Date of publication: 1 November 1993

Number of pages: 101-115

\section{Electronic reference}

Richard Proudfoot, "Shakespeare's Coinage », Actes des congrès de la Société française Shakespeare [Online], 11 | 1993, Online since 01 January 2007, connection on 22 April 2019. URL : http:// journals.openedition.org/shakespeare/1258 ; DOI : 10.4000/shakespeare.1258

This text was automatically generated on 22 April 2019

(C) SFS 
Shakespeare’s Coinage

\author{
Richard Proudfoot
}

